\title{
Metal Organic Vapor Phase Epitaxy of Thick N-Polar InGaN Films
}

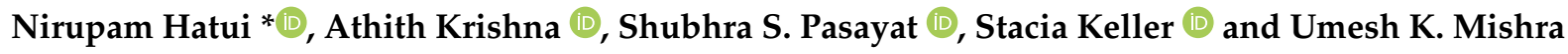

check for updates

Citation: Hatui, N.; Krishna, A.;

Pasayat, S.S.; Keller, S.; Mishra, U.K. Metal Organic Vapor Phase Epitaxy of Thick N-Polar InGaN Films. Electronics 2021, 10, 1182. https:// doi.org/10.3390/electronics10101182

Academic Editors: Ning Tang, Bo Shen, Liwen Sang and Guangxu Ju

Received: 23 April 2021

Accepted: 10 May 2021

Published: 15 May 2021

Publisher's Note: MDPI stays neutral with regard to jurisdictional claims in published maps and institutional affiliations.

Copyright: (c) 2021 by the authors. Licensee MDPI, Basel, Switzerland. This article is an open access article distributed under the terms and conditions of the Creative Commons Attribution (CC BY) license (https:/ / creativecommons.org/licenses/by/ $4.0 /)$.
Department of Electrical and Computer Engineering, University of California, Santa Barbara, CA 93106, USA; athith@ucsb.edu (A.K.); shubhra@ucsb.edu (S.S.P.); stacia@ece.ucsb.edu (S.K.); mishra@ece.ucsb.edu (U.K.M.)

* Correspondence: nirupam@ucsb.edu

\begin{abstract}
Hillock-free thick InGaN layers were grown on N-polar GaN on sapphire by metal organic vapor phase epitaxy using a digital growth scheme and $\mathrm{H}_{2}$ as surfactant. Introducing $\mathrm{Mg}$ to act as an additional surfactant and optimizing the $\mathrm{H}_{2}$ pulse time, In compositions up to $17 \%$ were obtained in $100 \mathrm{~nm}$ thick epilayers. Although Mg adversely affected the In incorporation, it enabled maintenance of a good surface morphology while decreasing the InGaN growth temperature, resulting in a net increase in In composition. The parameter space of growth temperature and $\mathrm{Mg}$ precursor flow to obtain hillock-free epilayers was mapped out.
\end{abstract}

Keywords: InGaN; N-polar; MOVPE

\section{Introduction}

The $(\mathrm{In}, \mathrm{Ga}) \mathrm{N}$ alloy system is attractive for various optoelectronic and electronic applications due to its tunable bandgap ranging from 0.7 to $3.4 \mathrm{eV}$ [1]. Thick InGaN films are especially of interest as relaxed base layers for InGaN based optoelectronic devices [2-5]. In addition, they are attractive for strain engineering, for example, to create light holes [6] or to obtain high frequency electronic devices, taking advantage of an increase in electron mobility due to the decrease in effective electron mass with increasing lattice constant $[7,8]$. Growing InGaN with higher In compositions by metal organic vapor phase epitaxy (MOVPE) is challenging because of the low thermal stability of $\operatorname{InN}$, which results in the growth temperature of InGaN films being significantly lower than the optimal growth temperature of GaN [9]. Thus, the growth temperature of InGaN layers has to be lower, the higher the targeted In content [10]. Low deposition temperatures often result in a low adatom surface mobility and inefficient $\mathrm{NH}_{3}$ pyrolysis [11,12], which can lead to increased defect formation. In addition, the lattice mismatch between InN and $\mathrm{GaN}$ is $10 \%$, and the thickness of InGaN layers grown on $\mathrm{GaN}$ is limited so as to suppress strain-related defect formation [13]. Thus, the InGaN critical layer thickness decreases with increasing In composition $[14,15]$. Although the direct growth of thick InGaN base layers on both GaN base layers and foreign substrates has been investigated [16-21], it remains difficult to produce high-quality thick InGaN layers without the formation of defects. In the case of films grown in the typical Ga-polar orientation by MOVPE, thick InGaN layers tend to relax via the formation of large V-pits, which increase in size as the layer thickness is increased [22-25]. Alternatively, thicker MOVPE-grown N-polar (000-1) InGaN films can exhibit hexagonal surface defects [26].

In the case of $\mathrm{N}$-polar films, $\mathrm{H}_{2}$ was shown to act as a surfactant enhancing the surface mobility of adsorbed species and suppressing the formation of hexagonal surface defects [26-30]. Lund et al. [31] were able to demonstrate $200 \mathrm{~nm}$ thick InGaN with an effective indium composition of $11 \%$ grown by MOVPE using a "digital" growth technique on relaxed N-polar InGaN pseudosubstrates grown by plasma-assisted molecular beam epitaxy (PAMBE). This growth technique takes advantage of the surfactant effect by introducing short $\mathrm{H}_{2}$ pulses during $\mathrm{InGaN}$ deposition, resulting in $\mathrm{InGaN} / \mathrm{GaN}$ short 
period superlattices (SLs) with individual layer thicknesses in the order of a few nanometers. The tradeoff was the decrease in In composition, because the presence of hydrogen in the growth ambient suppressed the incorporation of In into the crystal lattice $[24,25,32]$. Pasayat et al. [33] developed digital InGaN directly on $\mathrm{GaN}$-on-sapphire base layers and further optimized the digital growth process by introducing an additional $\mathrm{GaN}$ interlayer after every $40 \mathrm{~nm}$ of film, and demonstrated $200 \mathrm{~nm}$ thick N-polar InGaN films with an effective In composition of $8 \%$. Henceforth, we shall refer to the effective In composition of the layers grown using the digital method when describing their indium content.

In addition to $\mathrm{H}_{2}, \mathrm{Mg}$ has been shown to act as a surfactant in group-III nitride growth by MOVPE, leading, for example, to a significant increase in the lateral growth rate compared to the vertical growth rate when introduced during growth on patterned substrates [34]. Mg was shown to accumulate on the growing surface [35-37], increasing the surface mobility of adsorbed species. In the case of N-polar GaN deposition, addition of $\mathrm{Mg}$ suppressed the formation of hillocks by enhancing surface migration [38]. In this study, we investigated magnesium as an additional surfactant $[39,40]$ for the growth of thick N-polar digital InGaN layers, demonstrating $100 \mathrm{~nm}$ thick layers with an indium composition up to $17.1 \%$.

\section{Materials and Methods}

All epitaxial layers in this study were grown by MOVPE using the precursors trimethylgallium (TMGa), trimethylindium (TMIn), and ammonia $\left(\mathrm{NH}_{3}\right)$, on a c-plane sapphire substrate with a mis-orientation of $4^{\circ}$ in the a-direction. Unintentionally doped (UID) $1.5 \mu \mathrm{m}$ thick GaN buffer layers were first grown at $1200{ }^{\circ} \mathrm{C}$ as reported elsewhere [41]. The InGaN layers were grown on top of the $\mathrm{GaN}$ base layers using the digital growth approach, wherein $34.3 \mu \mathrm{mol} / \mathrm{min}$ TMIn and $4.8 \mu \mathrm{mol} / \mathrm{min}$ TMGa were injected with $222.5 \mathrm{mmol} / \mathrm{min}$ of $\mathrm{NH}_{3}$. The carrier gas was alternated between $45 \mathrm{~s}$ in $\mathrm{N}_{2}$ and 0 to $45 \mathrm{~s}$ in $\mathrm{H}_{2} / \mathrm{N}_{2}$, where $45 \mathrm{~s}$ corresponded to a layer thickness of about $2 \mathrm{~nm}$ [33]. This was continued for 25 to 50 loops to obtain 100 to $200 \mathrm{~nm}$ thick InGaN films. The composition was varied by decreasing the growth temperature from 910 to $820^{\circ} \mathrm{C}$. Bis(cyclopentadienyl)magnesium $\left(\mathrm{C} \mathrm{p}_{2} \mathrm{Mg}\right)$ was introduced to utilize the surfactant effect of $\mathrm{Mg}$, and the $\mathrm{Cp}_{2} \mathrm{Mg}$ flow during InGaN growth was increased up to $48 \mathrm{nmol} / \mathrm{min}$. The surface morphology of the films was inspected with an optical microscope under $50 \times$ and $20 \times$ magnifications, corresponding to areas of $40 \times 30 \mu \mathrm{m}$ and $100 \times 75 \mu \mathrm{m}$, respectively, and further analyzed using atomic force microscopy (AFM) in tapping mode. A sample was termed hillock-free when multiple regions under $50 \times$ magnification showed no hillocks. The composition was determined using reciprocal space maps (RSM) obtained by X-ray diffraction (XRD) on a Philips diffractometer.

\section{Results and Discussion}

The first set of samples was grown without additional $\mathrm{Cp}_{2} \mathrm{Mg}$ injection using the previously developed approach, wherein TMIn and TMGa were injected throughout and the carrier gas was alternated between $2 \mathrm{~nm}$ in $\mathrm{N}_{2}$ and $2 \mathrm{~nm}$ in $\mathrm{H}_{2} / \mathrm{N}_{2}$ to investigate the limits of the digital growth scheme, by decreasing the growth temperature of $200 \mathrm{~nm}$ thick InGaN layers from 910 to $850^{\circ} \mathrm{C}$ in steps of $20^{\circ} \mathrm{C}$. Although the samples grown at 910 and $890^{\circ} \mathrm{C}$ had smooth morphology, very sparse hexagonal hillocks started to form on the surface of the sample grown at $870{ }^{\circ} \mathrm{C}$, which was found to have an In content of $8 \%$. When the growth temperature was further reduced to $850^{\circ} \mathrm{C}$, dense hexagonal hillocks formed on the sample surface, as shown in Figure 1 . Thus, $8 \%$ was the highest In composition we could obtain in the current scheme while maintaining a smooth surface.

To obtain InGaN layers with even higher In content and smooth surface morphology, the surfactant effect needs to be increased. However, increasing the thickness of the layer where $\mathrm{H}_{2}$ is introduced would be counterproductive to achieving a higher effective In content, because $\mathrm{H}_{2}$ suppresses the In incorporation into the InGaN crystal. Thus, we decided to explore $\mathrm{Cp}_{2} \mathrm{Mg}$ as an additional surfactant, and a flow of $48 \mathrm{nmol} / \mathrm{min}$ com- 
pletely eliminated the dense hillocks at a growth temperature of $850{ }^{\circ} \mathrm{C}$ (Figure 1), opening a potential pathway to higher In compositions without degrading the surface morphology.
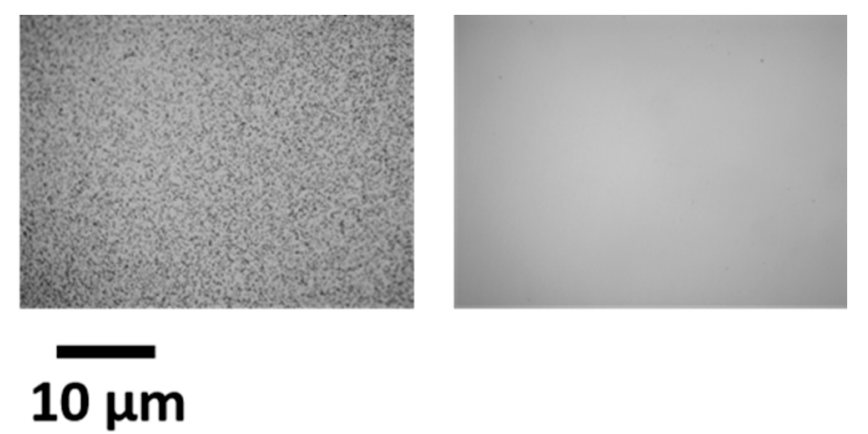

Figure 1. Optical microscopy images for samples grown at $850{ }^{\circ} \mathrm{C}$ (left) without $\mathrm{Cp}_{2} \mathrm{Mg}$, and (right) with $48 \mathrm{nmol} / \mathrm{min}$ of $\mathrm{Cp}_{2} \mathrm{Mg}$ flow.

Because $\mathrm{Mg}$ was now used as surfactant during $\mathrm{InGaN}$ growth, the layers with $\mathrm{H}_{2}$ pulses may not be as necessary. Decreasing the cycle time during which $\mathrm{H}_{2}$ was introduced during growth or possibly eliminating the entire step would lead to an immediate increase in the effective In composition. For the set of experiments exploring this parameter, the growth temperature was set to $840^{\circ} \mathrm{C}$, and the total InGaN layer thickness was decreased to $100 \mathrm{~nm}$ to maintain coherent growth despite the expected increase in the In composition and lattice mismatch. Decreasing the time of the $\mathrm{H}_{2}$ pulses by one-third and two-thirds showed no emergence of hillocks, as shown in Figure 2a-c. However, when the $\mathrm{H}_{2}$ pulses were entirely eliminated, dense hexagonal hillocks emerged on the sample surface. The AFM images taken from the samples in this series showed that although there were no hexagonal surface hillocks present, elongated rhombus-shaped features appeared as the time the $\mathrm{H}_{2}$ pulses were decreased (Figure 2). Note that the surface steps are typical of $\mathrm{N}$-polar films grown on miscut substrates [41]. As expected, the In composition increased with the decrease in the duration of the $\mathrm{H}_{2}$ pulse, and increased to $14.2 \%$ for the InGaN layer grown with only one-third of the original $\mathrm{H}_{2}$ insertion time (Figure 3) compared to $10.6 \%$ In for equal $\mathrm{N}_{2}$ and $\mathrm{H}_{2} / \mathrm{N}_{2}$ cycle times.

For the next experiments, a one-third reduced time of $\mathrm{H}_{2}$ pulse, corresponding to $2 \mathrm{~nm} \mathrm{InGaN} / 0.7 \mathrm{~nm} \mathrm{GaN}$ in each loop, and a $\mathrm{Cp}_{2} \mathrm{Mg}$ flow of $36 \mathrm{nmol} / \mathrm{min}$, were chosen. When the growth temperature was decreased from 840 to $820^{\circ} \mathrm{C}$, a very sparse coverage of hillocks was observed under low magnification $(100 \times 75 \mu \mathrm{m})$ in the optical microscope. The In composition for this InGaN layer was found to be $17.1 \%$. Decreasing the growth temperature further to $800{ }^{\circ} \mathrm{C}$ caused the hillocks to reappear, but these were largely eliminated by increasing the $\mathrm{Cp}_{2} \mathrm{Mg}$ flow to $48 \mathrm{nmol} / \mathrm{min}$. However, AFM images, presented in Figure 4, showed an increase in surface roughness due to the appearance of features similar to the elongated rhombus-shaped features measured for the sample depicted in Figure 2c Thus, the sample grown at $820^{\circ} \mathrm{C}$, using a $\mathrm{Cp}_{2} \mathrm{Mg}$ flow of $36 \mathrm{nmol} / \mathrm{min}$ and containing $17.1 \%$ In, was the sample with the highest composition exhibiting a hillock-free and smooth surface obtained in this study.

The morphology of the hillock-free sample grown at $800{ }^{\circ} \mathrm{C}$, which contained $19.8 \%$ In, indicated that the layer may have started relaxing via roughening, a well-known relaxation mechanism [42]; indeed, its RSM showed a relaxation of $23 \%$. Interestingly, the sample grown at $820^{\circ} \mathrm{C}$ containing $17.1 \%$ In with a smooth surface also showed $15 \%$ relaxation, which was unexpected because there was no indication of any relaxation via roughening from AFM shown in Figure 4. The sparse rhombus-like features should not have caused the relaxation as they were similar to those seen in the layer grown at $840^{\circ} \mathrm{C}$, which contained $11.1 \%$ In (Figure 2c) and was fully strained. The mechanism leading to the relaxation in the smooth samples is currently unclear and requires further study. 

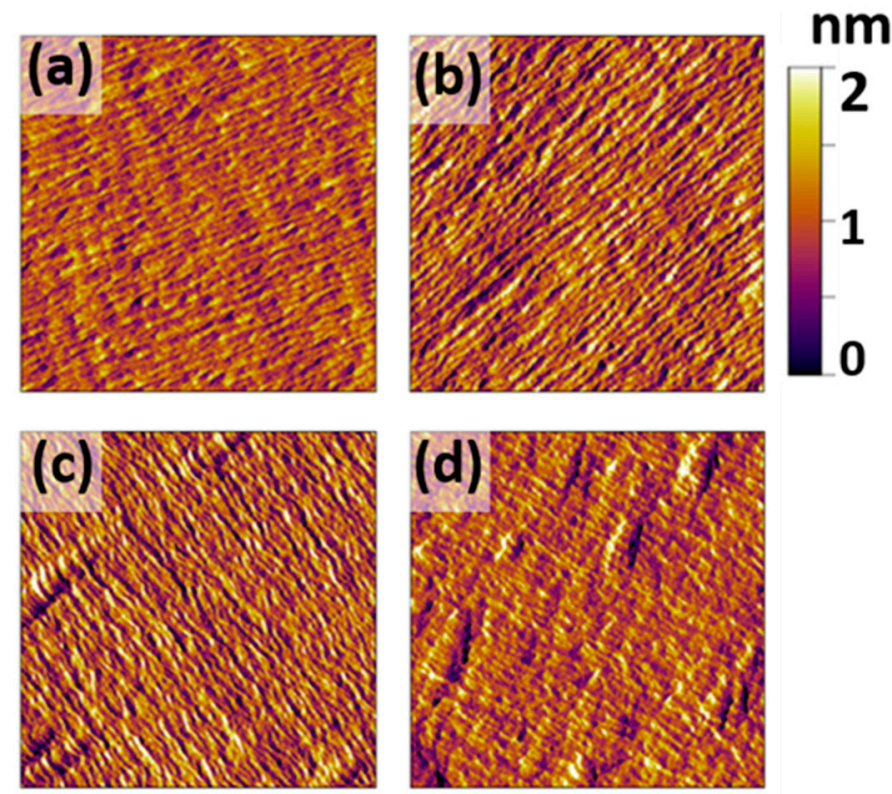

Figure 2. AFM amplitude images of $5 \times 5 \mu \mathrm{m}$ for InGaN grown with various superlattice (SL) compositions with a Cp $2 \mathrm{Mg}$ flow of $36 \mathrm{nmol} / \mathrm{min}$ : (a) $2 \mathrm{~nm} \mathrm{InGaN} / 2 \mathrm{~nm} \mathrm{GaN}$ (In = 11.1\%), (b) $2 \mathrm{~nm}$ $\mathrm{InGaN} / 1.4 \mathrm{~nm} \mathrm{GaN} \mathrm{(In} \mathrm{=} \mathrm{12.6 \% ),} \mathrm{(c)} 2 \mathrm{~nm} \mathrm{InGaN/0.7} \mathrm{nm} \mathrm{GaN} \mathrm{(14.2 \% ),} \mathrm{(d)} \mathrm{all} \mathrm{InGaN,} \mathrm{no} \mathrm{SL} \mathrm{(21.1 \% ).}$ Note that image (d) was taken in the area between the hexagonal surface hillocks.

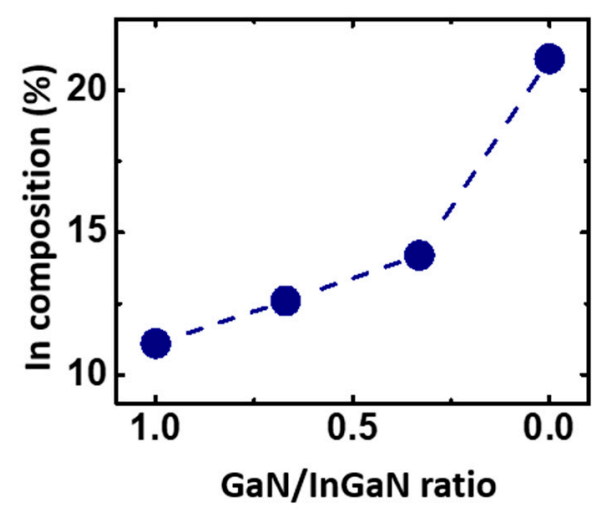

Figure 3. Effective In composition (measured by XRD) with decreasing hydrogen pulse time (resulting in decreasing GaN thickness in the SL). The samples were gown at $840{ }^{\circ} \mathrm{C}$ with a $\mathrm{Cp}_{2} \mathrm{Mg}$ flow of $36 \mathrm{nmol} / \mathrm{min}$. The surface morphology can be seen in Figure 2 with GaN/InGaN ratios of 1, 0.67, 0.33 , and 0 , corresponding to $(\mathbf{a}-\mathbf{d})$, respectively.
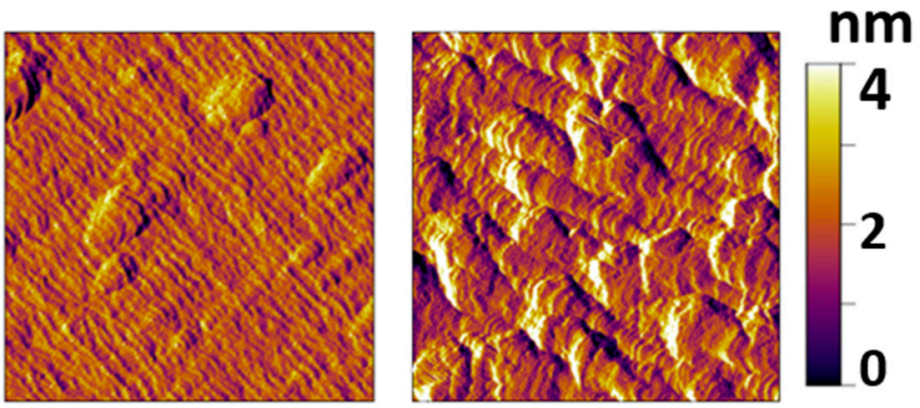

Figure 4. AFM amplitude images of $5 \times 5 \mu \mathrm{m}$ of InGaN grown at $820^{\circ} \mathrm{C}$ (left) $(\mathrm{In}=16.5 \%)$ and $800{ }^{\circ} \mathrm{C}$ (right) (In $=19.8 \%$ ). The samples were grown with a $\mathrm{Cp}_{2} \mathrm{Mg}$ flow of $48 \mathrm{nmol} / \mathrm{min}$.

Figure 5 summarizes the results obtained for all samples in this study, plotting the presence or absence of hillocks as a function of growth temperature and $\mathrm{Cp}_{2} \mathrm{Mg}$ flow. 
The graph illustrates the inverse relationship between $\mathrm{Cp}_{2} \mathrm{Mg}$ flow and growth temperature at the onset of hillock formation. The onset was defined for surfaces which exhibited hillocks under $20 \times$ magnification in the optical microscope, but no hillocks under $50 \times$ magnification. The samples at this onset are still termed hillock-free because they are suitable for device fabrication.

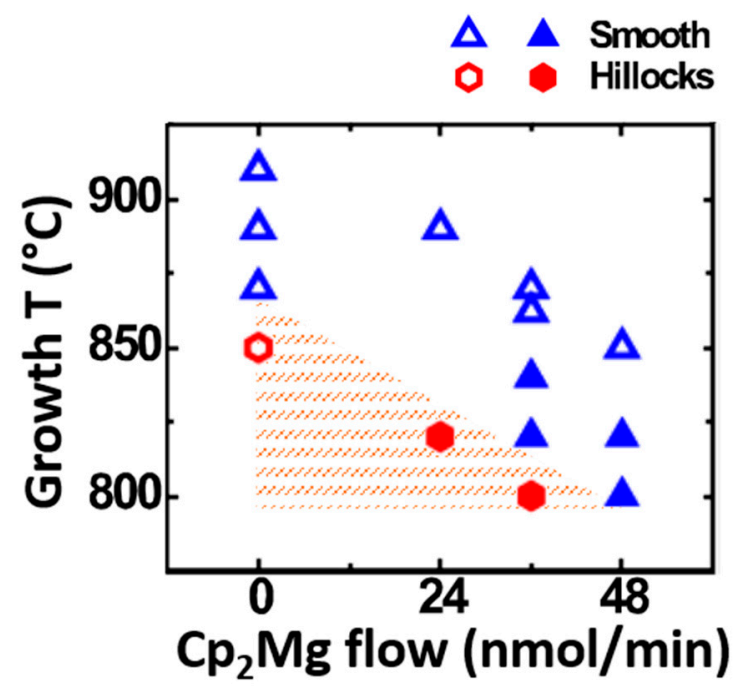

Figure 5. Chart of the presence of hillocks with varying temperature and $\mathrm{Mg}$ precursor flow. "Hillocks" are defined as samples showing hillocks under $50 \times$ magnification $(40 \times 30 \mu \mathrm{m})$. The empty symbols correspond to $200 \mathrm{~nm}$ thick layers, with $2 \mathrm{~nm}$ InGaN/2 nm GaN SLs, whereas filled symbols represent $100 \mathrm{~nm}$ thick layers with $2 \mathrm{~nm}$ InGaN/0.7 nm GaN SLs. The shaded region shows the growth parameter range in which hillocks will appear, and the hypotenuse marks the samples which are hillock-free under $50 \times$ magnification, but show some hillocks under $20 \times$ magnification.

Figure 6 illustrates the impact of the $\mathrm{Cp}_{2} \mathrm{Mg}$ addition on the In composition of the digital InGaN layers. Heavy Mg doping to the order of $10^{21} \mathrm{~cm}^{-3}$ was previously reported to cause a decrease in In incorporation in Ga-polar InGaN films [43]. Although our Mg doping was $\sim 9 \times 10^{19} \mathrm{~cm}^{-3}$ (determined from GaN:Mg SIMS calibration samples), it nonetheless adversely affected the In incorporation. For both samples grown at 870 and $820^{\circ} \mathrm{C}$, the In composition decreased with increasing the $\mathrm{Mg}$ precursor injection (Figure 6). Nevertheless, because the presence of Mg enabled the deposition of smooth InGaN films at lower temperatures, a higher In composition in the digital InGaN films could be achieved.

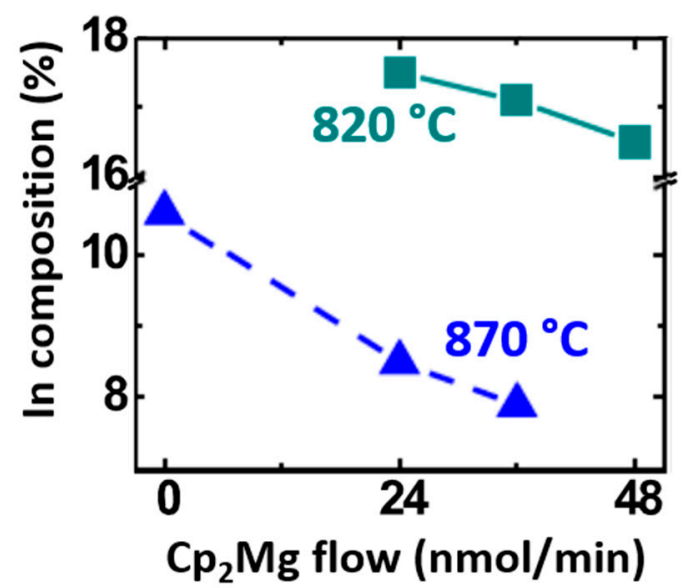

Figure 6. In composition as a function of $\mathrm{Mg}$ precursor flow at two different growth temperatures. 


\section{Conclusions}

In conclusion, InGaN layers with In composition of $17.1 \%$ and good surface morphology were demonstrated using a digital growth method using both $\mathrm{H}_{2}$ and $\mathrm{Cp}_{2} \mathrm{Mg}$ as surfactants. Although the presence of $\mathrm{Mg}$ adversely affected the In incorporation, the $\mathrm{Mg}$ addition enabled hillock-free growth at lower temperatures and growth of InGaN layers with an overall higher In content.

Author Contributions: Conceptualization, N.H., A.K., S.S.P. and S.K.; methodology, N.H. and S.K.; software, N.H.; validation, N.H. and S.K.; formal analysis, N.H. and S.K.; investigation, N.H., A.K. and S.S.P.; resources, S.K. and U.K.M.; data curation, N.H. and A.K.; writing-original draft preparation, N.H. and S.K.; writing-review and editing, N.H., S.K. and U.K.M.; visualization, N.H.; supervision, S.K. and U.K.M.; project administration, S.K. and U.K.M.; funding acquisition, U.K.M. All authors have read and agreed to the published version of the manuscript.

Funding: This work was supported in part by the ONR (Paul Maki) and the Semiconductor Research Corporation (SRC) and DARPA under the ComSenTer JUMP program.

Conflicts of Interest: The authors declare no conflict of interest.

\section{References}

1. Langer, T.; Kruse, A.; Ketzer, F.A.; Schwiegel, A.; Hoffmann, L.; Jönen, H.; Bremers, H.; Rossow, U.; Hangleiter, A. Origin of the "green gap": Increasing nonradiative recombination in indium-rich GaInN/GaN quantum well structures. Phys. Status Solidi C 2011, 8, 2170-2172. [CrossRef]

2. Nakamura, S.; Senoh, M.; Iwasa, N.; Nagahama, S. Superbright Green InGaN Single-Quantum-Well-Structure Light-Emitting Diodes. Jpn. J. Appl. Phys. 1995, 34, L1332. [CrossRef]

3. Chichibu, S.; Azuhata, T.; Sota, T.; Nakamura, S. Spontaneous emission of localized excitons in InGaN single and multiquantum well structures. Appl. Phys. Lett. 1996, 69, 4188-4190. [CrossRef]

4. Narukawa, Y.; Kawakami, Y.; Funato, M.; Fujita, S.; Fujita, S.; Nakamura, S. Role of self-formed InGaN quantum dots for Role of self-formed InGaN quantum dots for emitting at $420 \mathrm{~nm}$. Appl. Phys. Lett. 1997, 70, 981. [CrossRef]

5. Mukai, T.; Narimatsu, H.; Nakamura, S. Amber InGaN-Based Light-Emitting Diodes Operable at High Ambient Temperatures. Jpn. J. Appl. Phys. 1998, 37, L479. [CrossRef]

6. Gupta, C.; Tsukada, Y.; Romanczyk, B.; Pasayat, S.S.; James, D.-A.; Ahmadi, E.; Keller, S.; Mishra, U.K. First demonstration of improvement in hole conductivity in c-plane III-Nitrides through application of uniaxial strain. Jpn. J. Appl. Phys. 2019, $58,030908$. [CrossRef]

7. Li, W.; Pasayat, S.; Guidry, M.; Romanczyk, B.; Zheng, X.; Gupta, C.; Hatui, N.; Keller, S.; Mishra, U.K. First experimental demonstration and analysis of electrical transport characteristics of a GaN-based HEMT with a relaxed InGaN channel. Semicond. Sci. Technol. 2020, 35, 075007. [CrossRef]

8. Dreyer, C.E.; Janotti, A.; van de Walle, C.G. Effects of strain on the electron effective mass in GaN and AlN. Appl. Phys. Lett. 2013, 102, 142105. [CrossRef]

9. Nakamura, S.; Senoh, M.; Iwasa, N.; Nagahama, S. High-Brightness InGaN Blue, Green and Yellow Light-Emitting Diodes with Quantum Well Structures. Jpn. J. Appl. Phys. 1995, 34, L797. [CrossRef]

10. Matthews, J.W.; Blakeslee, A.E. Defects in epitaxial multilayers. J. Cryst. Growth 1974, 27, 118. [CrossRef]

11. Matsuoka, T.; Yoshimoto, N.; Sasaki, T.; Katsui, A. Wide-Gap Semiconductor InGaN and InGaAln Grown by MOVPE. Available online: https: / / dl.acm.org/doi/10.1007/BF02655831 (accessed on 1 May 2021).

12. Keller, S.; Mishra, U.K.; DenBaars, S.P. Flow Modulation Epitaxy of Indium Gallium Nitride. J. Electron. Mater. 1997, $26,10$. [CrossRef]

13. Reed, M.J.; El-Masry, N.A.; Parker, C.A.; Roberts, J.C.; Bedair, S.M. Critical layer thickness determination of GaN/InGaN/GaN double heterostructures. Appl. Phys. Lett. 2000, 77, 4121. [CrossRef]

14. Holec, D.; Costa, P.M.F.J.; Kappers, M.J.; Humphreys, C.J. Critical thickness calculations for InGaN/GaN. J. Cryst. Growth 2007, 303, 314. [CrossRef]

15. Leyer, M.; Stellmach, J.; Meissner, C.; Pristovsek, M.; Kneissl, M. The critical thickness of InGaN on (0 0 01)GaN. J. Cryst. Growth 2008, 310, 4913. [CrossRef]

16. Matsuoka, T.; Sasaki, T.; Katsui, A. Growth and properties of a wide-gap semiconductor InGaN. Optoelectronics Devices and Technol. 1990, 5,53 .

17. Keller, S.; Keller, B.P.; Kapolnek, D.; Abare, A.C.; Masui, H.; Coldren, L.A.; Mishra, U.K.; DenBaars, S.P. Growth and characterization of bulk InGaN films and quantum wells. Appl. Phys. Lett. 1996, 68, 3147. [CrossRef]

18. Shimizu, M.; Kawaguchi, Y.; Hiramatsu, K.; Sawaki, N. MOVPE growth of thick homogeneous InGaN directly on sapphire substrate using AlN buffer layer. Solid-State Electron. 1997, 41, 145. [CrossRef] 
19. Singh, R.; Doppalapudi, D.; Moustakas, T.D.; Romano, L.T. Phase separation in InGaN thick films and formation of InGaN/GaN double heterostructures in the entire alloy composition. Appl. Phys. Lett. 1997, 70, 1089. [CrossRef]

20. Yang, L.-H.; Zhang, B.-H.; Guo, F.-Q. Characteristics of an Indium-Rich InGaN p-n Junction Grown on a Strain-Relaxed InGaN Buffer Layer. Chin. Phys. Lett. 2013, 30, 047301. [CrossRef]

21. Choi, J.-H.; Shojiki, K.; Tanikawa, T.; Hanada, T.; Katayama, R.; Matsuoka, T. Investigation of indium incorporation into InGaN by nitridation of sapphire substrate in MOVPE. Phys. Status Solidi C 2013, 10, 417. [CrossRef]

22. Wu, X.H.; Elsass, C.R.; Abare, A.; Mack, M.; Keller, S.; Petroff, P.M.; DenBaars, S.P.; Speck, J.S. Structural origin of V-defects and correlation with localized excitonic centers in InGaN/GaN multiple quantum wells. Appl. Phys. Lett. 1998, 72, 692. [CrossRef]

23. Cho, H.K.; Lee, J.Y.; Yang, G.M.; Kim, C.S. Formation mechanism of V defects in the InGaN/GaN multiple quantum wells grown on GaN layers with low threading dislocation density. Appl. Phys. Lett. 2001, 79, 215. [CrossRef]

24. Wang, H.; Jiang, D.S.; Jahn, U.; Zhu, J.J.; Zhao, D.G.; Liu, Z.S.; Zhang, S.M.; Qiu, Y.X.; Yang, H. Investigation on the strain relaxation of InGaN layer and its effects on the InGaN structural and optical properties. Physica B 2010, 405, 4668-4672. [CrossRef]

25. Zal Balushi, Y.; Redwing, J.M. The effect of polarity on MOCVD growth of thick. Appl. Phys. Lett. 2017, 110, 022101. [CrossRef]

26. Keller, S.; Li, H.; Laurent, M.; Hu, Y.; Pfaff, N.; Lu, J.; Brown, D.F.; Fichtenbaum, N.A.; Speck, J.S.; DenBaars, S.P.; et al. Recent progress in metal-organic chemical vapor deposition of $(000 \overline{1}) \mathrm{N}-$ polar group-III nitrides. Semicond. Sci. Technol. 2014, $29,113001$. [CrossRef]

27. Northrup, J.E.; Neugebauer, J. Indium-induced changes in Ga(0001) surface morphology. Phys. Rev. B 1999, 60, R8473(R). [CrossRef]

28. Keller, S.; Fichtenbaum, N.A.; Furukawa, M.; Speck, J.S.; DenBaars, S.P.; Mishra, U.K. Growth and characterization of N-polar InGaN/GaN multiquantum wells. Appl. Phys. Lett. 2007, 90, 191908. [CrossRef]

29. Shojiki, K.; Tanikawa, T.; Choi, J.-H.; Kuboya, S.; Hanada, T.; Katayama, R.; Matsuoka, T. Red to blue wavelength emission of N-polar $(000 \overline{1})$ InGaN light-emitting diodes grown by metalorganic vapor phase epitaxy. Appl. Phys. Express 2015, 8, 061005. [CrossRef]

30. Hatui, N.; Krishna, A.; Li, H.; Gupta, C.; Romanczyk, B.; Acker-James, D.; Ahmadi, E.; Keller, S.; Mishra, U.K. Ultra-high silicon doped N-polar GaN contact layers grown by metal-organic chemical vapor deposition. Semicond. Sci. Technol. 2020, $35,095002$. [CrossRef]

31. Lund, C.; Hestroffer, K.; Hatui, N.; Nakamura, S.; DenBaars, S.P.; Mishra, U.K.; Keller, S. Digital growth of thick N-polar InGaN films on relaxed InGaN pseudosubstrates. Appl. Phys. Express 2017, 10, 111001. [CrossRef]

32. Piner, E.L.; Behbehani, M.K.; El-Masry, N.A.; McIntosh, F.G.; Roberts, J.C.; Boutros, K.S.; Bedair, S.M. Effect of hydrogen on the indium incorporation in InGaN epitaxial films. Appl. Phys. Lett. 1997, 70, 461. [CrossRef]

33. Pasayat, S.S.; Lund, C.; Tsukada, Y.; Catalano, M.; Wang, L.; Kim, M.J.; Nakamura, S.; Keller, S.; Mishra, U.K. Optimization of Digital Growth of Thick N-Polar InGaN by MOCVD. J. Electron. Mater. 2020, 49, 3450-3454. [CrossRef]

34. Beaumont, B.; Haffouz, S.; Gibart, P. Magnesium induced changes in the selective growth of GaN by metalorganic vapor phase epitaxy. Appl. Phys. Lett. 1998, 72, 921. [CrossRef]

35. Cheng, T.S.; Novikov, S.V.; Foxon, C.T.; Orton, J.W. Mechanisms of magnesium incorporation into GaN layers grown by molecular beam epitaxy. Solid State Commun. 1999, 109, 439. [CrossRef]

36. Xing, H.; Green, D.S.; Yu, H.; Mates, T.; Kozodoy, P.; Keller, S.; DenBaars, S.P.; Mishra, U.K. Memory Effect and Redistribution of Mg into Sequentially Regrown GaN Layer by Metalorganic Chemical Vapor Deposition. Jpn. J. Appl. Phys. 2003, 42, 50. [CrossRef]

37. Hashizume, T. Effects of Mg accumulation on chemical and electronic properties of Mg-doped p-type GaN surface. J. Appl. Phys. 2003, 94, 431. [CrossRef]

38. Tanikawa, T.; Shojiki, K.; Aisaka, T.; Kimura, T.; Kuboya, S.; Hanada, T.; Katayama, R.; Matsuoka, T. Enhancement of surface migration by $\mathrm{Mg}$ doping in the metalorganic vapor phase epitaxy of N-polar $(000 \overline{1}) \mathrm{GaN} /$ sapphire. Jpn. J. Appl. Phys. 2014, 53, 05FL05. [CrossRef]

39. Zhang, L.; Tang, H.F.; Schieke, J.; Mavrikakis, M.; Kuech, T.F. The addition of Sb as a surfactant to GaN growth by metal organic vapor phase epitaxy. J. Appl. Phys. 2002, 92, 2304. [CrossRef]

40. Junsong, C.; Xin, L.; Lubing, Z.; Shuang, Q.; Wei, G. Influence of initial growth conditions and Mg-surfactant on the quality of GaN film grown by MOVPE. J. Semicond. 2015, 36, 023005.

41. Keller, S.; Fichtenbaum, N.A.; Wu, F.; Brown, D.; Rosales, A.; DenBaars, S.P.; Speck, J.S.; Mishra, U.K. Influence of the substrate misorientation on the properties of N-polar GaN films grown by metal organic chemical vapor deposition. J. Appl. Phys. 2007, 102, 083546. [CrossRef]

42. Snyder, C.W.; Orr, B.G.; Kessler, D.; Sander, L.M. Effect of Strain on Surface Morphology in Highly Strained InGaAs Films. Phys. Rev. Lett. 1991, 66, 3032. [CrossRef] [PubMed]

43. Gherasoiu, I.; Yu, K.M.; Hawkridge, M.; Reichertz, L.A.; Walukiewicz, W. Mg induced compositional change in InGaN alloys. Semicond. Sci. Technol. 2019, 34, 025014. [CrossRef] 